\title{
Fruit Bronzing, a New Disease Affecting Jackfruit Caused by Pantoea stewartii (Smith) Mergaert et al.
}

\author{
${ }^{1}$ Ruben M. Gapasin, ${ }^{2}$ Garcia, R. P., ${ }^{2}$ Christine T. Advincula, ${ }^{3}$ De la \\ Cruz, C.S. and ${ }^{1,4}$ Lucia M. Borines
}

${ }^{1}$ National Abaca Research Center, Visca, Baybay City, Leyte, Philippines, ${ }^{2}$ Former Research Assistants, Visayas State University, Visca, Baybay City, Leyte,

Philippines, ${ }^{3}$ Dept. of Agriculture Regional Field Unite 8

Kanhuraw Hills, Tacloban City, Department of Pest Management

Visayas State University, Visca, Baybay City, Leyte, Philippines

\begin{abstract}
Jackfruit bronzing, an unreported disease affecting jackfruit is characterized by yellowish-orange to reddish discoloration of the affected pulps and rags of the fruit. The etiology of this disease, its isolation, pathogenicity, characterization and identification is the scope of this study. The pathogen was isolated from infected jackfruit, pathogenicity was conducted to detached and attached fruits. The pathogen was identified based on its cultural and morphological characteristics, staining reactions, physiological and biochemical characteristics, other plant inoculations and DNA analysis using the polymerase chain reaction (PCR). The bacterium produces yellow pigment in culture, Gram negative, slightly pleomorphic non-motile, facultatively anaerobic short-rods, measuring 1$2 \mathrm{um}$ in length, catalase positive, hydrolyzes gelatin and starch but not tween 80 , produces acid from glucose, galactose, fructose and sucrose but not from lactose and maltose. It did not produce hypersensitivity to tobacco, caused pits on potato discs but not soft rot. It infected pineapple fruits causing localized lesions and infected corn producing the same symptom as bacterial wilt or Stewart's disease. PCR analysis confirmed the cause as Pantoea stewartii (or Pantoea stewartii subsp. Stewartii (Smith) Mergaert et al)., formerly Erwinia stewartii (Smith) Dye.
\end{abstract}

Keywords: Bronzing, Jackfruit, Pantoea, Etiology, PCR

Correspondence: L.M. Borines Address: Department of Pest Management, Visayas State University, Visca, Baybay City, Leyte, Philippines E-mail: lucyborines@gmail.com Tel: 053-335-2626

DOI: 10.32945/atr3612.2014 


\section{INTRODUCTION}

Jackfruit (Artocarpus heterophyllus Lam.) is one of the popular and the most widely grown fruit species in the Philippines (Pinoy Farmer, 2008; Acedo, 1992). It is famous in the world because it is the largest edible fruit that weighs as much as $50 \mathrm{~kg}$ (DA-EVIARC, 2003). Jackfruit has many reported uses and widely adapted to a range of growing conditions which may had caused its wide cultivation (Haq, 2006; DA-EVIARC, 2012; Khan et al., 2003; Elevitch and Manner, 2006).

Aside from the edible fruit which can be consumed ripe or green for vegetable, the jackfruit tree can provide many other uses in environmental protection. It may be used in watershed rehabilitation. It is highly tolerant to wind and can be used as windbreaks or border plantings. It can provide feed for livestock, shade, and long-term timber. It is easy to grow and more adaptable than some of the other common Artocarpus species such as breadfruit (A. altilis; Elevitch and Manner, 2006). The primary economic product, however is the fruit which is sweet and tasty but the immature green fruit can be used as vegetable (Haq, 2006).

The area of jackfruit production in the Philippines in 2010 was 4,428 ha and a total production volume of 48,410 metric tons (BAS 2011). Despite jackfruits' versatility, it was only recently when the tree gained popularity when this commodity was considered as "flagship" commodity in Eastern Visayas. Since then its production was promoted to farmers by the Department of Agriculture. The NSIC-registered jackfruit variety called "EVIARC Sweet" is claimed by scientists in the region as the sweetest and the best jackfruit variety ever. It has a taste and aroma far more superior than all the rest.

An unreported disease, locally named "jackfruit bronzing" has been occasionally found affecting the fruits. The name implies the typical yellowish orange to reddish discoloration of the affected pulps and rags inside the jackfruit when opened (Fig. 1) and with the external appearance of the fruit as symptomless. Once affected, the fruit quality is compromised and can deter the consumers and processors. The disease is yet unreported and the etiology unstudied hence this research.

The study was particularly conducted at the Department of Pest Management, Visayas State University, Visca, Baybay City, Leyte from April, 2009 to March 2012 to: isolate, conduct pathogencity, characterize and identify the cause of fruit bronzing disease affecting jackfruit. 


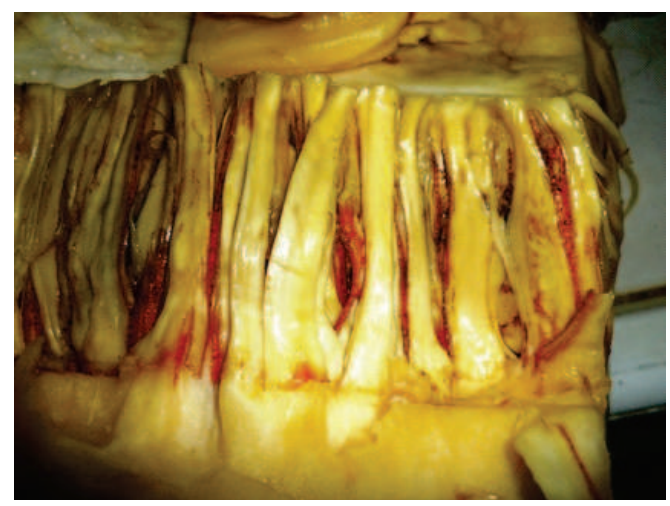

Figure 1. Naturally infected jackfruit showing the symptom of bronzing disease.

\section{MATERIALS AND METHODS}

\section{Pathogen Isolation and Pathogenicity Tests}

Jackfruits that were affected with bronzing were collected from jackfruit plantations in the island of Leyte and were brought to the plant disease diagnostic laboratory, at the Visayas State University for initial diagnosis and isolation of the pathogen. A standard technique of bacterial isolation was followed using Nutrient Agar (NA) medium. Pathogenicity was conducted by injecting $10 \mathrm{ml}$ of $10^{8} \mathrm{cfu} \mathrm{ml}^{-1}$ of the bacterial isolates to disinfected detached and attached healthy fruits. After two weeks incubation, the inoculated fruits were sliced to examine for the development of bronzing symptoms. The pathogen was re-isolated from infected fruits and re-inoculated to attached and detached fruits to confirm pathogenicity.

\section{Characterization and Identification of the Pathogen}

The bacterial isolates that produced the typical symptom of the disease were subjected to a series of tests, the approach was narrowing down the possible genera of known plant pathogenic bacteria until the right identification was arrived. The cultural and morphological characteristics, pigmentation and staining reactions were studied. To determine whether the pathogenic bacterium is motile of not, a hanging drop preparation of the bacterium was prepared and observed under the compound microscope. The isolates were tested in a Ralstonia solanacearum detection kit (Pocket Diagnostic Kit of Forsite Diagnostics, Sand Hutton, 
York, UK) to rule out Ralstonia solanacearum from the possible causes since the symptom type in jackfruit is similar to "Bugtok" disease of banana.

The isolates were also subjected to potato test to determine whether they can cause soft rotting to determine whether the causal bacterium belong to the soft rotting Erwinia or Pectobacterium spp. To test for $\mathrm{O}_{2}$ requirement, the bacteria were stab inoculated to tubed Hugh and Leifson medium ( $5 \mathrm{~g}$ glucose, $5 \mathrm{~g}$ beef extract, $14 \mathrm{mg}$ bromcresol purple, $17 \mathrm{~g}$ agar, $1 \mathrm{~L}$ dH20). Duplicate tubes were left open and another two were covered with 1 inch thick liquefied paraffin mixture (1:1 mixture of petroleum jelly and paraffin) and incubated for 7 days. To test for the production of catalase enzyme, a drop of $3 \% \mathrm{H}_{2} \mathrm{O}_{2}$ was placed on flame sterilized glass slide. A loopful of a48-hr old culture of the bacterial isolate was stirred onto the drop and observed for the presence of bubbling which indicates the release of $\mathrm{O}_{2}$ and positive catalase test.

To test for the utilization of starch the bacteria were streaked to starch agar plates (3g beef extract, 3g yeast extract, $20 \mathrm{~g}$ soluble starch, $20 \mathrm{~g}$ agar to $1 \mathrm{~L} \mathrm{dH}_{2} \mathrm{O}$ ) and incubated for 48 hours. The plates were then flooded with $\mathrm{I}_{2} \mathrm{KI}$ solution to determine presence of clear zones around the colony growth which indicates positive starch hydrolysis. To test for Tween 80 hydrolysis, agar medium made up of $(10 \mathrm{ml}$ tween $80,10 \mathrm{~g}$ bactopeptone, $5 \mathrm{~g}$ $\mathrm{NaCl}, 0.1 \mathrm{~g} \mathrm{CaCl}_{2} \cdot 2 \mathrm{H}_{2} \mathrm{O}, 20 \mathrm{~g}$ agar to $1 \mathrm{~L} \mathrm{dH}_{2} \mathrm{O}$ ) was streaked with the bacteria and incubated for 2 days. To test for the bacterium's ability to liquefy gelatin, a medium composed of $3 \mathrm{~g}$ beef extract and $120 \mathrm{~g}$ Bacto-gelatin to $1 \mathrm{~L} \mathrm{dH}_{2} \mathrm{O}$ was stab inoculated with the bacterium and incubated at room temperature. After 3, 7 and 14 days after inoculation, the tubes were placed at $4^{\circ} \mathrm{C}$ for $30 \mathrm{~min}$ then brought out and gently tipped. Flowing of the media when tipped signifies positive gelatin liquefaction.

For tobacco hypersensitivity test, a homogenous suspension of test organism with $10^{8} \mathrm{cfuml}^{-1}$ was prepared. Together with sterile water alone and Escherichia coli (negative control) and Ralstonia solanacearum (positive control), they were infiltrated on the underside of tobacco leaves using a $1 \mathrm{ml}$ syringe.

To test for acid production from carbohydrates, the test bacterium was inoculated to $1 \%$ concentration of the following sugars: glucose, galactose, fructose, maltose, sucrose and lactose in a basal medium (2g Peptone, $5 \mathrm{~g}$ $\mathrm{NaCl}, 0.3 \mathrm{~g} \mathrm{~K}_{2} \mathrm{HPO}_{4}$ to $1 \mathrm{Li}$ sdH2O with $1.6 \%$ alcoholic solution per liter bromthymol blue). The inoculated tubes were observed daily for change in color from bluish green to yellow which indicates utilization of the sugar and acid production by the bacterium. 


\section{Inoculations to Other Plants}

When the genera of the causal bacterium was nearly ascertained, it was inoculated to possible host plants of the suspected genus which included cucumber, corn and pineapple fruitlet. One $\mathrm{ml}$ of $1 \mathrm{x} 10 \mathrm{cfu} / \mathrm{ml}$ bacterium was injected to the stem of cucumber, corn and fruit of pineapple. One $\mathrm{ml}$ sterile water was injected separately which served as control.

\section{PCR-Based DNA Analysis}

One of the plants mentioned above were positively infected with the bacterium showing typical symptoms of a previously reported well known disease. A literature search was then conducted for a PCR-based method of detecting that particular species. The work of Coplin et al. 2002 was found and so the bacterium was subjected to DNA extraction and PCR analysis using species-specific primers to confirm the identity of the pathogen.

\section{DNA Extraction}

The bacterium was grown on nutrient broth $(3 \mathrm{~g}$ beef extract, $5 \mathrm{~g}$ peptone to $1 \mathrm{~L} \mathrm{dH}_{2} \mathrm{O}$ ) for $48 \mathrm{hrs}$. Five $\mathrm{mL}$ sterile water was pipetted and placed on bacterial culture and bacterial growth was then scraped. The bacterium was pelleted out of this suspension in a microcentrifuge tube. An $665 \mu \mathrm{L}$ extraction buffer $(1 \mathrm{M}$ Tris- $\mathrm{HCl} \mathrm{pH} 8.0,5 \mathrm{M} \mathrm{NaCl}, 0.5 \mathrm{M}$ ethylenediaminetetraacetic acid (EDTA) pH 8.0) was added to the pellet, shaken and placed on ice. The sample was allowed to boil for 5 minutes to break open the cells and inactivate enzyme nuclease, afterwhich, $35 \mu \mathrm{L}$ of $20 \%$ SDS and $5 \mu \mathrm{L}$ of proteinase $\mathrm{K}$ was added and spin. The mixture was incubated for $10 \mathrm{~min}$ at $65^{\circ} \mathrm{C}$ in a water bath and added with $115 \mathrm{M} \mathrm{NaCl}$ and mixed well by gentle inversion until samples were suspended. A $90 \mu \mathrm{L}$ CTAB was added and then incubated at $65^{\circ} \mathrm{C}$ for $10 \mathrm{~min}$. Nine hundred $\mu \mathrm{L}$ of chloroform was added, mixed, spin for 2,000rpm for 7 minutes. The supernatant was transferred into a clean tube and added with $600 \mu \mathrm{L}$ isopropanol then gently mixed, spin for $5 \mathrm{~min}$ and rinsed three times with $70 \%$ ethyl alcohol. Lastly, the DNA was allowed to air dry and added with $20 \mu \mathrm{L} 1 \mathrm{x}$ Tris-EDTA (TE) buffer and stored at $-20^{\circ} \mathrm{C}$ until use.

To check for DNA quality, the samples were run together with known concentrations of DNA in $0.8 \%$ agarose gel in $0.5 \mathrm{X}$ TBE buffer at 90 volts for $1 \mathrm{hr}$, stained with ethidium bromide, and viewed in a UV trans-illuminator connected to an Alpha Digi-Doc documentation system. 


\section{PCR and Thermocycling Conditions}

Two sets of primers CPSL1 and CPSR2c and ES16 and ESIG2c (Coplin et al., 2002) were used in PCR reactions which were carried out in total volume of $25 \mu \mathrm{l}$. Each reaction was composed of $25 \mathrm{pmol}$ of each primer, $10 \mathrm{X}$ buffer, $50 \mathrm{mM} \mathrm{MgCl}_{2}, 10 \mathrm{mM}$ dNTPs and 1 unit Taq enzyme with $2 \mu \mathrm{l}(50$ ng $\mathrm{ml}^{-1}$ ) template DNA. The thermo-cycling profile includes: initial denaturation at $94^{\circ} \mathrm{C}$ one cycle for 1 minute and subsequent cycles for 15 seconds, annealing of primer for 15 seconds at $55^{\circ} \mathrm{C}$ and polymerization at $72^{\circ} \mathrm{C}$ for 30 seconds. After 25 cycles, the PCR product was stored at $4^{\circ} \mathrm{C}$ and later separated on a $1 \%$ agarose gel ( 1.5 hours at $90 \mathrm{~V})$, stained with ethidium bromide, and documented as above.

\section{RESULTS AND DISCUSSION}

\section{Pathogen Isolation and Pathogenicity Tests}

Field-collected jackfruits that were affected with bronzing showed rusty, reddish discoloration which affected the pulp and rags. Microscopic examination of the samples revealed plenty of bacteria oozing from sections of the affected jackfruit pulp. After subjecting this ooze to Gram staining, the dominant bacteria present there were stained pink or were Gram negative, slightly pleomorphic rods.

Between colony types on isolation plates (i.e., whitish and yellowish) the yellowish bacterium produced the typical jackfruit bronzing symptom. The point of inoculation showed a yellow discoloration which visibly started from the point of injection, which spread into the base and to the rags (Fig. 2).The same type of symptoms was observed in re-inoculated fruits. The bronzing symptom on the artificially inoculated fruits however was lighter compared to in fruits that are naturally infected most likely because the inoculated fruits were opened after just two weeks after inoculation and the infection was still at an early stage. In a naturally infected fruits, usually infection might have occurred earlier and the fruits are usually opened when it is ripe such that the disease incubation is longer.

Cultural/morphological, physiological and biochemical studies of fruit bronzing bacterium

The yellow bacterium that showed infection to jackfruit produced punctiform to circular flat yellowish colonies with entire margin and 
translucent density on NA. Agar stroke was beaded and has moderate amount of growth. A summary of the key tests towards its identification is shown in table 1. The pure culture isolates are Gram negative (Fig. 3) slightly pleomorphic, non-capsulated and non-spore-forming short-rods measuring 1-2 $\mathrm{m}$. The bacteria under a hanging drop preparation exhibited no motility (Table 1$)$.

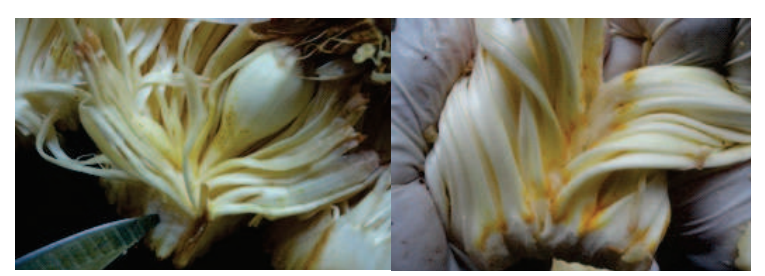

Figure 2. Jackfruit injected with the bronzing bacterium showing the typical symptom at 2 weeks after inoculation.

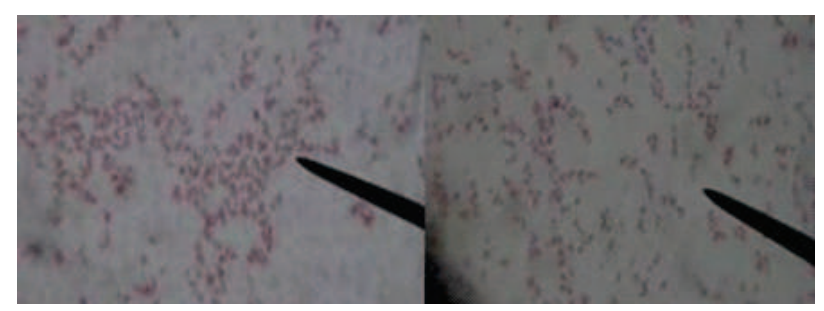

Figure 3. Gram stained cells of the bronzing bacterium showing Gram negative slightly pleomorphic rods. (1000X).

The causal bacterium tested negative to Ralstonia solanacearum (Fig. 4), so it's not the same as the causal organism of "Bugtok" disease. The bacterium positively utilized starch and gelatin indicating the production of enzyme $\beta-1,4$ glucan maltohydrase (amylase) and protease but it did not hydrolyze tween 80 indicating the non-production of enzyme lipase. It did not produce hypersensitivity to tobacco even up to three days after inoculation (Table 1; Figure 5). Tobacco hypersensitivity test is useful for identifying Xanthomonas spp., the Pseudomonas group, and Erwinia amylovora (Fahy and Persley, 1983). The causal organism therefore was not among these bacteria.

The pathogen produced bubbling but not so profuse when added with $\mathrm{H}_{2} \mathrm{O}_{2}$ indicating a limited production of enzyme catalase. In the test for $\mathrm{O}_{2}$ 
requirement, it grew in both open and closed tubes but it grew better and produced more yellowing in closed tubes and in the deeper portion of the open tube (Figure 6). This suggests that it grew better in an anaerobic condition and yellowing of the medium from the original purple color, especially in the closed tubes also suggests that the bacterium produce acid in the medium and therefore has a fermentative type of metabolism. These characteristics belong to the Enterobacteriaceae where the genus Erwinia and related genera belong. Facultatively-anaerobic plant pathogenic bacteria usually belongs to the Erwinia species (Winslow et al. 1920) or any of the new genera that emerged from this genus such as Pectobacterium and Brenneria (Hauben et al., 1999), Enterobacter (Hormaeche and Edwards 1960), Dickeya (Samson et al., 2005) and Pantoea (Gavini et al. 1989). The pathogen though did not caused soft rotting on potato, just lesions and therefore do not belong to soft rotting Erwinia or Pectobacterium spp. (Fig.7). The bacterium was able to utilize and produced acid from glucose, galactose,fructose sucrose and maltose for the disaccharides tested and but it did not utilize lactose (Table 1).

Table 1. Summary of selected tests done on the bronzing bacterium.

\begin{tabular}{ll}
\hline TEST & RESULT \\
\hline Gram staining & Gram negative \\
Capsule staining & Non-capsulated \\
Endospore staining & Non-endospore former \\
Motility & Non-motile (observed Brownian movement) \\
Test for Ralstonia & - (shows the "C" band only, not the "T" band) \\
solanacearum & \\
Catalase Reaction & + (slight bubbling) \\
$\mathrm{O}_{2}$ Requirement & Facultative anaerobe (Growth in both open and \\
& close tubes) \\
Potato test & Lesion/pit not soft rot \\
Starch Hydrolysis & + (Utilized starch in the medium) \\
Tween80 hydrolysis & - (no opaque haloes around colonies) \\
Gelatin liquifaction & + (hydrolyzed gelatin) \\
Tobacco Hypersensitivity & - (no necrosis of infiltrated tissues) \\
Acid from Carbohydrates & + for glucose, galactose, fructose, maltose and \\
& sucrose \\
\hline
\end{tabular}

\section{Inoculations to Other Plants}

Results of the previous tests had narrowed down the choices of the cause to Gram negative facultatively-anaerobic rod-shaped bacteria which produces yellow colony on NA. Most plant pathogenic bacteria with yellow 
colony in culture belong to genus Xanthomonas or and some formerly Erwinia spp. Xanthomonas was out of the possibility since it is a strict aerobe and the bronzing pathogen is a facultative anaerobe. We were then left with the non-soft rotting Erwinia species reported in the Philippines as the possible cause that include: Erwinia tracheiphila (formerly Bacillus tracheiphilus, Smith, 1895), the cause of bacterial wilt of cucurbits, Erwinia ananas (now Pantoea ananatis; Serrano 1928) Mergaert et al.1993) the cause of fruitlet rot of pineapple and Erwinia stewartii (now Pantoea stewartii (Smith 1898) Mergaert et al. 1993). This led us to inoculate cucumber, pineapple and corn with the bronzing bacterium.

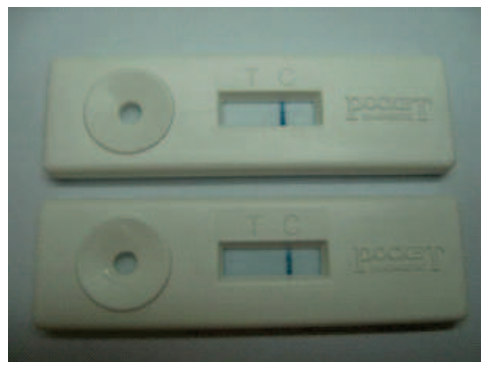

Figure 4. R. solanacearum test kit showing a negative test.

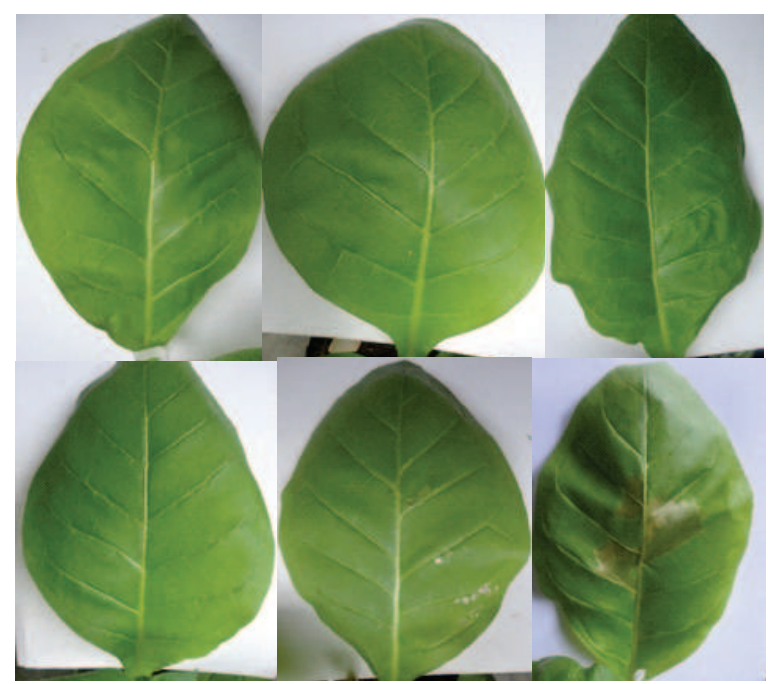

Figure 5. Leaves of tobacco infiltrated with the bronzing bacterium showing showing negative hypersensitivity (a-c), sterile water (d) and E.coli (e) (- checks); and Ralstonia solanacearum (f) (+ check). 


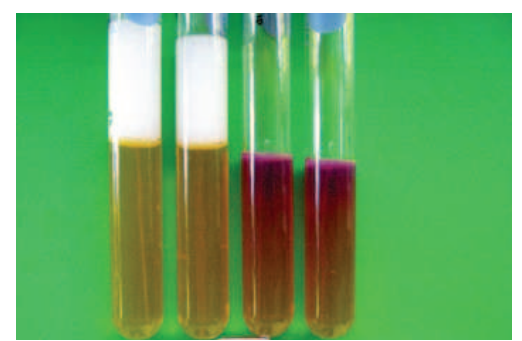

Figure 6. Growth of the bacterium in both open tubes and tubes sealed with paraffin mixture and with more acid produced in the closed tube indicating that the bacterium is a facultative anaerobe.

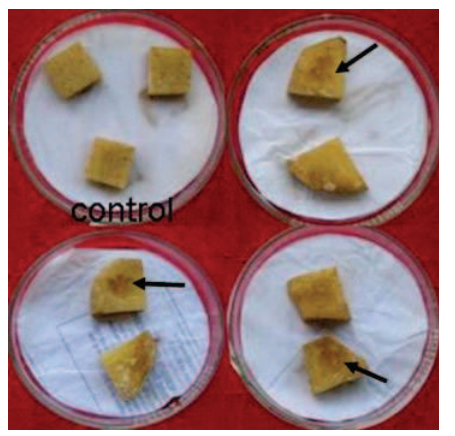

Figure 7. Inoculated potato slices showing pits or lesions with no tissue maceration or soft rotting indicating that the bacterium is not a soft rotting Erwinia or Pectobacterium sp.

No infections resulted to the inoculation to cucumber but as early as 5 days after inoculation, a typical symptom of Stewart's disease or bacterial wilt has been observed in inoculated corn. The symptom appeared as palegreenish to whitish linear streaks with irregular or wavy margins that runs parallel to leaf veins starting at the base (Fig. 8). Pineapple was also infected but producing a localized rotting symptom which did not progress. With this result, the jackfruit bronzing pathogen was tentatively identified as Pantoea stewartii (formerly Erwinia stewartii) but it could be very closely related to Pantoea ananatis, the cause of fruitlet rot of pineapple since the bacterium also caused a more or less localized rotting to pineapple fruit. This was possible because $P$. stewartii and $P$. ananatis are very closely related. A subspecies of Pantoea stewartii subsp. indologenes had been isolated from pineapple (Mergaert et al., 1993; http://www.tgw1916.net/Enterobacteria /Pantoea.html). On the other hand, Pantoea ananatis had been reported to affect corn in Poland, causing leaf spotting symptom (Krawczyk et al., 2010). 


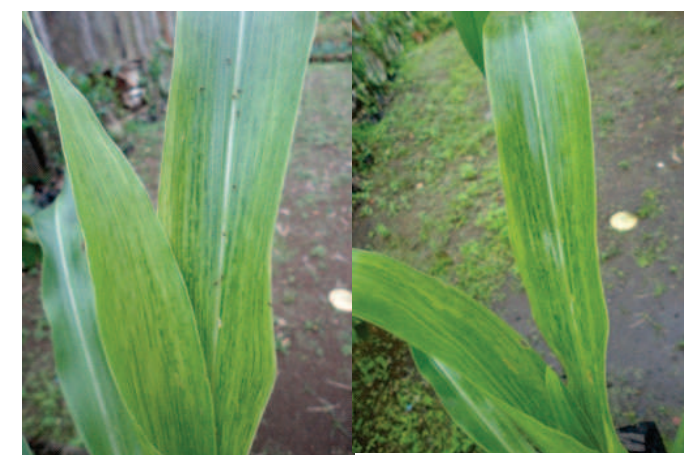

Figure 8. Corn plants inoculated with the jackfruit bronzing bacterium showing the typical leaf symptoms of bacterial wilt or Stewart's disease.

Confirmation of the Identity of the Pathogen Through the Polymerase Chain Reaction

Two Pantoea stewartii-specific primers from Coplin and Majerczak (2002) were used in PCR reactions. The primers were CPSL1 (5' CCTGTCAGTCTCGAACC 3') and CPSR2c (5' ATCTCGAACCGGTAACC 3') which encodes synthesis of capsular polysaccharide stewartan and ES16 (5' GCGAACTTGGC-AGAGAT 3') and ESIG2c (5' GCGCTTGCGTGT-TATGAG 3') from the 16S-23S rRNA/ITS region of the bacterium.

Initially, a PCR-reaction was performed using the DNAs of pure culture isolates using the two sets of primers previously mentioned. The expected band for Pantoea stewartii was positively amplified from the jackfruit bronzing bacterium using both the two primer pairs used. CPSL1/CPSR2c primers positively amplified the $\sim 1.1 \mathrm{~kb}$ fragment (Fig. 9), while the ES16/ESIG2c primers amplified the 0.92-kb fragment (Fig. 10). Another PCR analysis was conducted CPSL1 and CPSR2 P. stewartii-specific primer using DNAs extracted from healthy jackfruit, old and new pure cultures of the bacteria and bacterial ooze from fruit infected with bronzing disease. The result is shown in Figure 11. The expected $1.1 \mathrm{~kb}$ band was positively shown on DNAs of the old and new isolates of the bacterium, as well as from the fresh disease specimen (bacterial ooze from jackfruit with bronzing symptom) which confirmed the cause as Pantoea stewartii. Another shorter band size fragment was amplified from the DNAs extracted from the bacterial ooze from a jackfruit bronzing specimen (Ao1 and Ao2) suggesting for the possible presence of another strain or another bacterium, possibly secondary invader, and this is expected since the ooze is not a pure culture of the bronzing bacterium. 


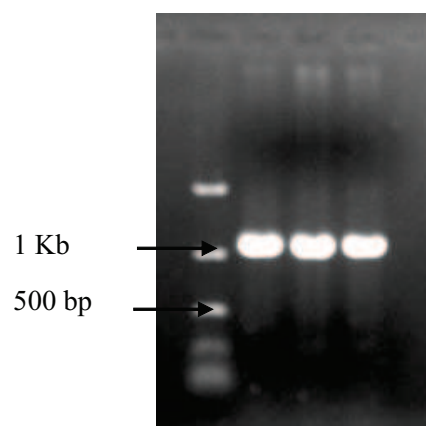

Figure 9. Amplification product from the bronzing bacterial DNA using theCPSL1 and CPSR2c Pantoea stewartii-specific primershowing the expected $1.1 \mathrm{~Kb}$ band. (M-Marker; Lanes 1-3 are amplified DNAs of jackfruit bronzing isolates).

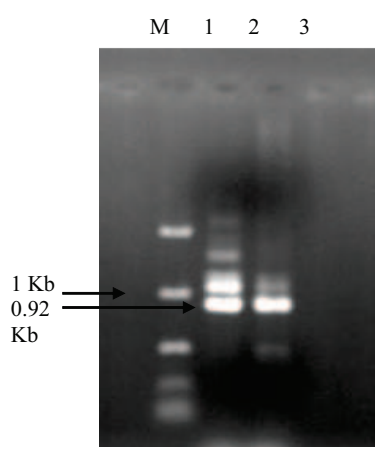

Figure 10. Amplification product from the bronzing bacterial DNA using the ES16 and ESIG2c Pantoea stewartii-specific primer showing the expected 0.92 band. (M - DNA Marker; 1-2-DNAs of jackfruit bronzing isolates).

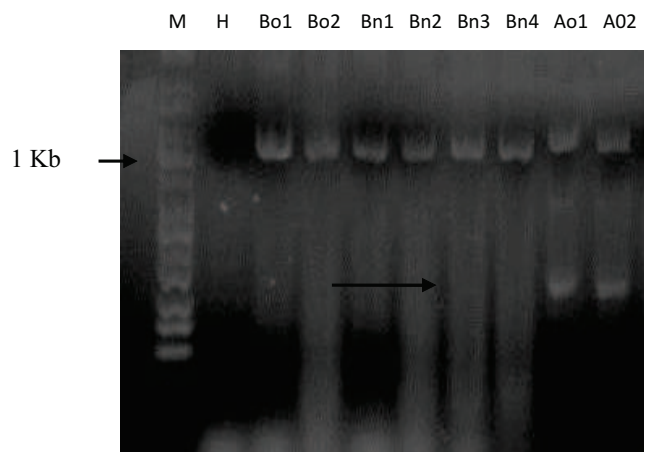

Figure 11. Amplification product using the CPSL1 and CPSR2c Pantoea stewartii-specific primer from DNAs of healthy $(\mathrm{H})$, old (Bo1 and Bo2) and new (Bn1-BN4) pure culture isolates of the bacteria and bacterial ooze from bronzing-affected fruit (Ao1 and Ao2), showing the $1.1 \mathrm{~Kb}$ expected P. stewartii band. Note that another shorter band was amplified from the bacterial ooze from fruit affected with bronzing disease. 


\section{CONCLUSION}

Jackfruit bronzing is caused by a bacterium that also infected corn. It produced the typical bacterial wilt or Stewart's disease symptom in corn and localized rotting in pineapple fruit suggesting that the cause of this disease is a Pantoea species. The identity of the causal organism was established to be Pantoea stewartii (formerly Erwinia stewartii) through several tests and confirmed through PCR using Pantoea stewartii-specific primers. The mode of bacterial dissemination in the field needs further study.

\section{ACKNOWLEDGMENT}

The authors would like to acknowledge the following: the Philippine Council for Agriculture and Aquatic Resources Research and Development (PCAARRD) for funding this research; Dr. Anthony Young of the Department of Primary Industries, Brisbane Queensland, Australia for the technical consultations and references provided; DA-RIARC, Abuyog and selected farmers for the permission to inoculate fruits of selected trees. Special thanks are also given to Rosalyn Binongo, Rosario Calamba and Rhea Argallon for assistance in the final stages of the research.

\section{REFERENCES}

Acedo, A. L. 1992. Jackfruit biology, use, production and Philippine research.Multipurpose Tree Species Trees Network Series. Winrock International Institute for Agricultural Development.51 pp.

BAS (Bureau of Agricultural Research). 2011. http://countrystat.bas.gov. $\mathrm{ph} /$ ?cont=10\&pageid=1\&ma=P00LUAHO.

COPLIN, DL, MAJERCZAK, DR, ZHANG, Y., KIM, WS., JOCK, S. AND GEIDER, K. 2002. Identification of Pantoea stewartii subsp. stewartii by PCR and Strain Differentiation by PFGE. Plant Disease. 86:304-311.

DA-EVIARC (retrieved, January 2012). Jackfruit. Agriculture and Fisheries Information Service. http://www.trc.dost.gov.ph/trcfile/Technology -Snapshots/Farming-Tips/jackfruit.pdf

DA-EVIARC. 2003. Jackfruit. Agriculture and Fisheries Information Service, Department of Agriculture. $7 \mathrm{pp}$. 
ELEVITCH, C.E. and H.I. MANNER. 2006. Artocarpus heterophyllus (jackfruit). Species Profiles for Pacific Island Agroforestry. p.2. Retrieved from http://www.agroforestry.net/tti/ A.heterophyllusjackfruit.pdf

FAHY, P C, and PERSLEY, G J,. 1983. Plant Bacterial Diseases: A Diagnostic Guide. Academic Press, New York. 393 pp.

GAVINI, F., MERGAERT, J., BEJI, A., MIELCAREK, C., IZARD, D., KERSTERS, K. and DE LYE, J. 1989. Transfer of Enterobacter agglomerans (Beijerinck 1888) Ewing and Fife 1972 to Pantoea gen. nov. as Pantoea agglomerans comb. nov. and description of Pantoea dispersa sp. nov. International Journal of Systematic Bacteriology 39: 337-345.

HAQ N. 2006. Jackfruit Artocarpus heterophyllus. J.T. WILLIAMS, J.T., SMITH, R.W., and DUNSIGER, Z. eds. Southampton Center for Underutilized Crop. University of Southampton, West Sussex, U.K.

HAUBEN, L,MOORE, ERB, VAUTERIN, L, STEENACKERS, M, MERGAERT, J, VERDONCK, L, SWINGS, J, 1999. Validation and publication of new names and new combinations previously effectively published outside the IJSB. International Journal of Systematic Bacteriology 49: 1-3.

HORMAECHE E. AND EDWARDS P.R. 1960. A proposed genus Enterobacter. International Bulletin of Bacteriological Nomenclature and Taxonomy 10: 71-74.

KHAN, M.R., OMOLOSO, A.D. and KIHARA, M.. 2003. Antibiotic activities of Artocarpus heterophyllus. Fitoterapia. 75(5):501-505.

KRAWCZYK, K., KAMASA, J., ZWOLINSKA, A. and POSPIESZNY, H. 2010. First report of Pantoea ananatis associated with leaf spot disease of maize in Poland. Journal of Plant Pathology (2010), 92 (3), 807-811.

MERGAERT, J, VERDONCK, L AND KERESTERS, K. 1993. Transfer of Erwinia ananas (synonym, Erwinia uredovora) and Erwiniastewartii to the genus Pantoea emend. as Pantoea ananas(Serrano 1928) comb. nov. and Pantoea stewartii (Smith1898) comb. nov., respectively, and description of Pantoeastewartii subsp. indologenes subsp. nov. International Journalof Systematic Bacteriology 43: 162-173. 
PINOYFARMER, 2008. Jackfruit Farming. AgriPinoy.net. Retrieved from http://blog.agriculture.ph/jackfruit-growing-in-the-philippines.html

SAMSON, R., LEGENDRE, J.B., CHRISTEN, R., FISCHER-LE SAUX, M., ACHOUAK, W. and GARDAN, L., 2005. Transfer of Pectobacterium chrysanthemi (Burkholder et al.,1953) Brenner et al.,1973 and Brenneria paradisiaca to the genus Dickeya gen. nov. as Dickeya chrysanthemi comb. nov. and Dickeya paradisiaca comb. nov. and delineation of four novel species, Dickeya dadantii sp. nov., Dickeya dianthicola sp. nov., Dickeya dieffenbachiae sp. nov. and Dickeya zeae sp. nov. International Journal of Systematic and Evolutionary Microbiology 55:1415-1427.

SERRAN0, F.B. 1928. Bacterial fruitlet brown-rot of pineapple in the Philippines. Philippine Journal of Science 36, 271-305.

SMITH, E.F. 1898. Notes on Stewart's sweet-corn germ. Pseudomonas stewarti, n. sp. Proceedings of the American Association for the Advancement of Science 47, 422-426.

SMITH, E.F. 1895. Bacillus tracheiphilus sp. nov., die Ursache des Verwelkens verschiedener Cucurbitaceen. Centralblatt für Bakteriologie und Parasitenkunde 2, 1,364-373.

WINSLOW, C.E.A., BROADHURST, J., BUCHANAN, R.E., KRUMWIEDE, C., ROGERS, L.A. and SMITH, G.H., 1920. The families and genera of the bacteria. Final report of the committee of the Society of American Bacteriologists on characterization and classification of bacterial types. Journal of Bacteriology 5:191-229. 